УДК 62.09:001 - 051 (571)

ББК 79.100+72.471.9+85.127.5

DOI 10.31554/2222-9175-2019-34-195-207

\title{
Г. М. Запорожченко
}

\section{МЕМОРИААЬНЫЕ КОМНАТЫ ИЗВЕСТНЫХ УЧЕНЫХ КАК ФОРМА ПУБАИЧНОЙ ПАМЯТИ}

Мемориальные комнаты известных ученых занимают заметное место в структуре научных учреждений Российской академии наук. Особое внимание в статье уделено коммеморации жизни и деятельности ученых Сибирского отделения РАН. Изучены содержание, особенности функционирования и значение мемориальных комнат для развития в современном обществе институтов науки и гражданственности. Предложенная и интерпретированная метареальность мемориальных комнат известных ученых проанализирована в концепте наследия как одна из форм публичной памяти.

Ключевые слова: мемориальная комната, наука, наследие, формы публичной памяти, Российская академия наук, Сибирское отделение РАН.

\section{G. M. Zaporozhchenko}

\section{MEMORIAL ROOMS OF FAMOUS SCIENTISTS AS A FORM OF PUBLIC MEMORY}

Memorial rooms of famous scientists occupy a prominent place in the structure of scientific institutions of the Russian Academy of Sciences. Particular attention is paid to the commemoration of the life and work of scientists of the Siberian branch of the RAS. The content, features of functioning and significance of memorial rooms for development of institutes of science and citizenship in modern society are studied. The proposed and interpreted metareality of memorial rooms of famous scientists is analyzed in the concept of heritage as one of the forms of public memory.

Keywords: memorial room, science, heritage, forms of public memory, Russian Academy of Sciences, Siberian branch of RAS.

$\mathrm{B}$ современную эпоху перехода от стихийного развития человечества («отчужденной истории») к управляемой социоприродной эволюции возрастает значение общественного интеллекта, человеческого капитала, науки и образования. Процесс передачи накопленных ценностей во всех областях науки выдвигает теоретические и практические задачи перед специалистами в области наследия. Проблемы освоения и актуализации наследия являются сегодня важным объектом научной рефлексии. Значительный вклад в их разработку внес Томислав С. Шола хорватский ученый, всемирно признанный специалист в области наследия и музеологии, один из учредителей Европейской ассоциации наследия и движения «Best in Heritage» («Лучшие в наследии»).

Согласно его подходу, наследие отличается от истории активным и деятельным включением людей [Шола 2017: 43]. Прошлое - это то, что мы хотим задокумен-

ЗАПОРОЖЧЕНКО Галина Михайловна - доктор исторических наук, ведущий научный сотрудник Федерального государственного бюджетного учреждения науки «Институт истории Сибирского отделения РАН» (Новосибирск, Россия). E-mail: galinakoop@yandex.ru. 
тировать, чтобы оно стало наследием, с которым мы начинаем работать и транслировать. Т. С. Шола отмечает, что «наследие - это всегда система общих ценностей, сформированных на основе отбора и оценки того, что необходимо и достойно памяти, которую следует хранить» [Шола 2017: 47]. Наследие - это конструкт, в основе которого могут лежать, в т. ч., научные и образовательные цели [Там же: 57]. В рамках выдвинутого им концепта мнемософии - науки о публичной памяти как новой целостной области социогуманитарных наук Т. С. Шола указывает, что природа наследия выявляется через баланс музеализациии и коммуникации, между реальным и отраженным «Я», между материальным и нематериальным наследием [Там же: 170-171]. Таким образом, он поднимает важную проблему функционирования институтов публичной памяти, которые служат общественным инструментом наследия. «Наследие и публичная память работают как мощное противоядие против дезинтеграции и разрушения системы жизненно важных ценностей», - полагает ученый, подчеркивая важность обновления и развития институтов публичной памяти для общества [Там же: 68].

Одной из важных форм публичной памяти являются мемориальные комнаты. Мемориальные комнаты известных ученых занимают заметное место в структуре научных учреждений Российской академии наук. Целью данной статьи является изучение содержания, особенностей функционирования и значения данной формы публичной памяти для развития в современном обществе институтов науки и гражданственности.

Мемориальные комнаты известных ученых принадлежат к группе музейных объектов, которые создаются преимущественно путем фиксирующей музеефикации, т. е. сохранения в неприкосновенном виде подлинной обстановки, окружавшей выдающегося человека. Возникновение мемориальных музеев на основе квартир и кабинетов деятелей науки началось в 1910-е гг. и одной из первых в 1911 г. была музеефицирована квартира Д. И. Менделеева при Петербургском университете.

В 1940 г. был открыт музей М. В. Ломоносова (1711-1765). Музей, созданный на его родине, в деревне Мишанинской (ныне Ломоносово) Архангельской области, представляет в основном предметы, ретроспективно характеризующие быт окрестных поселений. В созданном в 1947 г. музее М. В. Ломоносова в кунсткамере в Санкт-Петербурге, где размещался Институт антропологии и этнографии АН СССР, экспонировалось некоторое количество сохранившихся до нашего времени принадлежавших ученому вещей (серебряное блюдо с монограммой, документы - паспорт, выданный на проезд из Петербурга в Марбург, диплом на звание профессора Петербургской академии наук, грамота на владение землей в Копорском уезде) [Карпеев 1998: 221-231].

Мемориальный музей-квартира создателя научной физиологической школы, первого российского лауреата Нобелевской премии академика И. П. Павлова (18491936) существует с 1949 г. в Санкт-Петербурге. Музей расположен в построенном в 1808-1809 гг. по проекту А. Захарова здании, принадлежащем Академии наук, и входит в состав Института физиологии им. И. П. Павлова РАН [Куприянова 1998: 213-220].

Мемориальный кабинет-музей академика В. И. Вернадского (1863-1945), выдающегося ученого-естествоиспытателя, мыслителя и общественного деятеля, был создан в 1953 г. в Институте геохимии и аналитической химии имени В. И. Вернадского в Москве. Не застыв безжизненным мемориалом, музей стал активным научно-исследовательским центром, площадкой для так называемого кружка Вернадского - сотрудников научно-исследовательских институтов, стремившихся более близко познакомиться с научным наследием великого ученого [Ивановская 2013: 60-79]. 
Мемориальный кабинет-музей академика А. П. Виноградова (1895-1975), видного ученого-геохимика, деятельность которого связана с решением наиболее значительных научно-технических проблем XX столетия - созданием и развитием атомной промышленности и освоением космоса, соратника и преемника академика В. И. Вернадского, открыт в Институте геохимии и аналитической химии им. В. И. Вернадского в Москве [Виноградова 1998: 192-201].

Мемориальный кабинет-музей великого ученого, генетика, ботаника, селекционера, общественного деятеля, академика Н. И. Вавилова (1887-1943) открыт в 1987 г. в оранжерейном корпусе Института общей генетики РАН им. Н. И. Вавилова [Авруцкая 2005: 199-206].

Мемориальный дом-музей ученого-энциклопедиста и общественного деятеля (революционера-народника) Н. А. Морозова (1854-1946) открыт в Ярославской области, недалеко от так называемого «золотого кольца» древних русских городов, в бывшей дворянской усадьбе в местечке Борок, ставшей вследствие его деятельности ныне (неофициально) наукоградом и связанной также с деятельностью известного полярного исследователя И. Д. Папанина [Захарова 1998: 157-165].

Музей И. Д. Папанина, известного полярного исследователя, контр-адмирала, доктора географических наук, первого директора Института биологии внутренних вод АН СССР, созданного на берегу Рыбинского водохранилища в Ярославской области, открыт в 1989 г. в домике «финской постройки», где он жил, приезжая на работу в Борок [Камшилова 1998: 166-176].

Мемориальный кабинет выдающегося ученого-физиолога, одного из основоположников космической биологии и медицины, академика B. B. Парина в 2002 г. открыт в Институте медико-биологических проблем РАН в Москве. В нем представлено множество вещей из прижизненной квартиры ученого [Пономарева 2002: 266-292].

Дом-музей выдающихся химиков-органиков, академиков $A$. $E$. Арбузова (1877-1968) и Б. А. Арбузова (1903-1991) в Казани - один из немногих в нашей стране музеев, полностью сохранивших мемориальную обстановку. Музей с 1969 г. находится в Казани, в деревянном одноэтажном особняке постройки середины XIX в. и содержит более 20 тыс. подлинных экспонатов [Гайдукова 2002: 201-220].

Мемориальный кабинет-музей блестящего ученого, математика и механика, президента Академии наук СССР в 1961-1975 гг., академика M. В. Келдыша (19111978) открыт в 1981 г. в Институте прикладной математики РАН, в бывшем кабинете ученого - первого директора института [Езерова 1998: 201-212].

Мемориальный кабинет-музей выдающегося химика-органика, президента Академии наук в 1951-1961 гг., ректора Московского университета академика $A$. $H$. Несмеянова (1899-1980) создан при Институте элементоорганических соединений РАН в 1985 г. [Леонова 2012: 156-166].

Мемориальный музей ярчайшего ученого, основателя Института физических проблем РАН, одного из основателей Московского физико-технического института, нобелевского лауреата академика П. Л. Kanuu̧ь (1894-1984) открыт в 1985 г. в его коттедже в Москве, принадлежащем Академии наук [Рубинин 2012: 213-230].

Мемориальный кабинет крупного ученого, химика-органика, академика $C$. $C$. Наметкина (1876-1950) создан в 1974 г. в Институте нефтехимического синтеза им. А. В. Топчиева РАН в Москве [Нехаева, Паренаго 2002: 147-162].

Мемориальный кабинет крупнейшего ученого, физикохимика, организатора науки, академика $A$. Н. Фрумкина (1895-1976) создан в 2005 г. в Институте физической химии и электрохимии им. А. Н. Фрумкина РАН [Хрущева 2005: 173-187].

Мемориальный кабинет выдающегося ученого-химика, специалиста по полимерам, крупного организатора науки, академика Н. A. Платэ открыт в Институте 
нефтехимического синтеза им. А. В. Топчиева РАН в 2009 г. [Калашникова, Нехаева 2012: 165-176].

Опыт создания мемориальных комнат, кабинетов и музеев известных ученых получил широкое распространение и в созданном в конце 1950-х гг. Сибирском отделении АН - РАН.

До создания Сибирского отделения присутствие научных сил на огромной территории Сибири было сравнительно слабым. В основном кадры ученых были сосредоточены в столичных городах - Москве, Ленинграде, Киеве, Тбилиси. До того, как в Сибири оказались крупные ученые в связи с репрессиями (доктор физикоматематических наук Ю. Б. Румер), эвакуацией (академик С. А. Чаплыгин), а затем в связи с созданием в 1943 г. Западно-Сибирского филиала Академии наук СССР (академик А. А. Скочинский), на всю Сибирь был лишь один академик - томский физик В. Д. Кузнецов, который окончил в 1911 г. Петербургский университет. С созданием Сибирского отделения в Сибирь переехали на работу видные ученые страны, за ними последовали их ученики, выпускники вузов, аспиранты. Не только старейший в Сибири Томский государственный университет (основан в 1888 г.), но и Новосибирский государственный университет (основан в 1959 г.) стали кузницей академических кадров для сибирской науки в соответствии с триадой М. А. Лаврентьева «фундаментальная наука - внедрение инноваций в производство - интегрированная подготовка кадров».

На 1 января 2018 г. в Сибирском отделении РАН состояло 210 членов РАН: 107 академиков, 103 члена-корреспондента, 91 профессор. Всего в научных организациях занято 11345 научных работников, из них 2410 докторов, 6176 кандидатов наук [Покровский, Запорожченко, Шелегина 2018: 22-23].

Научно-организационный вклад ученых в развитие СО РАН является важным объектом коммеморации - культурной памяти и передачи традиций. В соответствии с общепринятыми в российской и мировой практике нормами и традициями память о выдающихся ученых увековечивается в названиях научно-исследовательских и учебных учреждений, минералов, планет, исследовательских кораблей, улиц, учебных аудиторий вузов.

Например, в Новосибирском академгородке ученым посвящено 6 памятников и 56 мемориальных досок, 9 улиц, 9 лесных тропинок, 13 институтов, 8 учебных аудиторий в НГУ, 22 стипендии для студентов и молодых ученых СО РАН названы именами ученых. Память о замечательной когорте ученых Сибирского отделения РАН бережно сохраняется в мемориальных комнатах, созданных в академических учреждениях.

В Институте гидродинамики СО РАН им. М. А. Лаврентьева создан мемориальный кабинет академика $M$. А. Лаврентьева-ученого с мировым именем, специалиста в области математики и механики, организатора и первого председателя СО АН СССР (1957-1975), основателя и первого директора Института гидродинамики СО АН (1957-1976). Заслуга М. А. Лаврентьева - в организации в Сибири крупных комплексных научных центров, в которых были созданы условия для развития междисциплинарных исследований, внедрения научных результатов в практику, подготовки кадров, комфортного проживания ученых. М. А. Лаврентьев внес огромный вклад в организацию вузов нового типа - Московского физико-технического института и Новосибирского государственного университета. М. А. Лаврентьев - кавалер многочисленных государственных наград, трижды лауреат государственных премий, почетный гражданин г. Новосибирска.

При активном участии директоров Института гидродинамики академиков РАН Л. В. Овсянникова (1976-1986) и В. М. Титова (1986-2004) кабинет М. А. Лаврен- 
тьева долгие годы сохранялся как мемориальный объект вместе с предметами интерьера, убранства и личными вещами ученого. В 2004 г. по инициативе директора Института, члена-корреспондента РАН В. М. Тешукова (2004-2008) начал создаваться объект музейного значения «Мемориальный кабинет академика М. А. Лаврентьева». На двери сохранена подлинная металлическая табличка «Директор Института академик М. А. Лаврентьев». Центральное место занимает рабочий стол, телефон с селекторной связью, часы марки «Стрела» в деревянной раме, школьная доска с мелом, в качестве необходимой дани эпохе - портрет В. И. Ленина. На стенах фотографии М. А. Лаврентьева с П. Л. Капицей, А. П. Александровым, В. М. Келдышем, президентами Франции Ш. де Голлем и Ж. Помпиду, Н. С. Хрущевым, А. Н. Косыгиным, известными учеными. Историческими являются фотосюжеты, где М. А. Лаврентьев запечатлен с родителями и Н. Н. Лузиным в Геттингене (1911), с «отцами-основателями» Сибирского отделения С. А. Христиановичем, А. А. Трофимуком и С. Л. Соболевым у макета строящегося Академгородка.

Интерес представляют фотоальбом о первом общем собрании Президиума Сибирского отделения Академии наук СССР 15-20 мая 1958 г., модель реактивного самолета - подарок от Новосибирского авиационного завода им. В. П. Чкалова, макет подводной лодки - подарок от Главного управления кораблестроением ВоенноМорского флота СССР, реверсивный и управляемый пневмопробойник для работы в мерзлых грунтах с образцом пробитой горной породы - подарок от коллектива Института горного дела СО АН СССР, гравюра с изображением плотины Красноярской ГЭС, построенной с использованием метода направленного взрыва, - подарок от красноярских гидростроителей. Ценными экспонатами являются рукописи М. А. Лаврентьева и книги с автографами известных ученых.

Часть экспонатов связана с признанием заслуг М. А. Лаврентьева и Института гидродинамики. Это фотоальбомы «Юбилейная V Международная конференция «Лаврентьевские чтения» в Новосибирском академгородке», памятная медаль «100-летие академика М. А. Лаврентьева», коллекция поздравительных телеграмм на имя директоров Института, дипломы о вручении Институту переходящего Красного знамени Совета Министров СССР и ВЦСПС $(1982,1985)$, диплом за разработку ресурсосберегающих технологий с использованием энергии взрыва (1987), дипломы ВДНХ (1974, 1984, 1985), международных и российских научно-технических и промышленных выставок и семинаров, Почетные грамоты Институту от Министерства машиностроения СССР, авиационного завода им. В. П. Чкалова, администрации Новосибирской области.

Успешная научно-исследовательская деятельность института отражена в аттрактивных экспонатах. Это макет песочных часов, наполненных ультрадисперсным нанопорошком, изобретенным в Институте в 1980-е гг.; подарок Институту в честь 25-летнего юбилея от Уралхиммаша в виде металлического круга, разделенного на сектора с помощью разработанных в Институте импульсных технологий.

Мемориальный кабинет активно используется в представительских целях, открыт для школьников и студентов, научно-образовательных мероприятий. Его материалы использовались при подготовке к публикации юбилейного издания «Век Лаврентьева», посвященного 100-летию М. А. Лаврентьева, международных научных конференций «Лаврентьевские чтения» в Новосибирске.

В 1998 г. в Институте органической химии СО РАН имени Н. Н. Ворожцова создана мемориальная библиотека-музей $B$. А. Коптюга (1931-1997) - академика, внесшего огромный вклад в развитие химической науки в Сибири, вице-президента РАН, ректора НГУ, директора Института органической химии, председателя СО РАН (1980-1997). В ее составе более двух тысяч книг из личной коллекции ученого 
с широким тематическим диапазоном, около 800 папок с архивными документами, отражающими функционирование Сибирского отделения, состояние науки в России, проблемы экологии, устойчивого развития общества, адептом которого был B. А. Коптюг, деятельность ученого в OHH, IUPAC, SCOPE и других международных организациях [http://turizmnso.ru/sights].

С 1970 г. в Институте физики СО АН - СО РАН в Красноярске действует мемориальный музей академика Л. В. Киренского (1909-1969) - Героя Социалистического Труда, создателя сибирской школы физиков-магнитологов, организатора и первого директора института, участника создания Красноярского государственного университета.

Мемориальный музей создан в помещении института на основе домашнего кабинета Л. В. Киренского и личной библиотеки. Тематико-хронологическая структура экспозиции соответствует биографической парадигме Л. В. Киренского и содержит разделы: «Детские и юношеские годы Л. В. Киренского» о периоде его жизни от рождения в 1909 г. в Якутии, в с. Амга, до поступления в Московский государственный университет; «Годы учебы в МГУ и начало научной деятельности»; «Годы работы в Красноярском государственном педагогическом институте (с 1939)», где ученый основал магнитную лабораторию, на основе которой в 1956 г. был создан Институт физики АН СССР, вошедший позднее в состав СО АН СССР.

Раздел «Годы и люди» создан к 50-летию института и посвящен деятельности Л. В. Киренского на посту директора института в 1957-1969 гг. Под его руководством было развито оригинальное направление в биофизике сложных систем - параметрическое управление биосинтезом, получены наиболее существенные в мировой науке результаты по созданию биолого-технических систем жизнеобеспечения. Демонстрируются материалы о увековечении памяти о Л. В. Киренском: его именем названы Институт физики СО РАН, улицы в Красноярске, с. Амге, теплоход, учреждены премия его имени для молодых ученых СО РАН и стипендия для студентов физико-математического факультета Красноярского государственного педагогического института. Многочисленные фотопортреты в моменты работы, общения с коллегами и близкими людьми дают представление о личности ученого и образе его поколения.

Демонстрируются уникальные мемориальные предметы обстановки домашнего кабинета ученого эпохи 1950-60-х гг.: письменный стол, диван, кресла, журнальный столик, письменный прибор, телефон, пишущая машинка, логарифмическая линейка, наручные и настольные часы, подстаканник, папка для подписей, музыкальные инструменты (мандолина, балалайка). Книги из личной библиотеки насчитывают 665 томов - по всему спектру исследований института. Представлены награды, сувениры, подарки, более ста поздравительных адресов. К уникальным экспонатам относятся фотографии семьи Киренских, учебники по математике, по которым занимались отец и сам Л. В. Киренский - «Руководство по арифметике», изданное в 1838 г., и «Арифметика», изданная в 1827 г., лекции академика АН Белоруссии Н. С. Акулова, записанные Л. В. Киренским в МГУ в 1934 г., переписка с односельчанами, дипломная работа Киренского-студента, диплом об окончании университета, рукописные лекции по магнетизму, прочитанные ученым в разные годы в Красноярском педагогическом институте.

Экспозицию дополняют видеокассеты с документальными фильмами о Л. В. Киренском, Красноярском академгородке, воспоминаниями, интервью, книга об ученом из серии «Наука Сибири в лицах». Музей имеет страницу на сайте института, поддерживает тесную связь с малой родиной академика в Якутии, где также имеется музей Л. В. Киренского. 
В Институте нефтегазовой геологии и геофизики СО РАН им. А. А. Трофимука в 2006 г. открылся мемориальный музей и библиотека академика $A$. A. Трофимука (1911-1999) - геолога-нефтяника, организатора и первого директора Института геологии и геофизики СО АН СССР (1957-1988), первого заместителя председателя Сибирского отделения АН СССР (1961-1988), за свою плодотворную деятельность названного главным геологом Сибири.

Мемориальный музей и библиотека академика А. А. Трофимука созданы по инициативе директора Института, академика А. Э. Конторовича (1997-2007). Перед входом в музей установлен памятник А. А. Трофимуку. Обширный фотоматериал освещает основные этапы жизни и трудовой биографии А. А. Трофимука: с родителями (1917); во время учебы на геолого-почвенном факультете Казанского университета (окончил в 1933 г.); на первой буровой нефтяного месторождения Кинзебулатово в Башкирии (1943); в момент вручения ордена Ленина в Кремле М. И. Калининым (1944); с «духовными отцами»- учителями академиком И. М. Губкиным и наркомом Серго Орджоникидзе; в качестве главного геолога Главнефтеразведки Миннефтепрома СССР (1952); историческое фото «Штаб геологической науки в Сибири» с академиками Института геологии и геофизики СО АН (1977); «Несколько слов с ехидцей»- момент разговора А. А. Трофимука с президентом АН СССР академиком А. П. Александровым о насущных проблемах озера Байкал (1982); встречи с А. Н. Косыгиным (1969), М. С. Горбачевым (1979), А. Лукашенко (1998) и другими политическими и общественными деятелями; среди делегатов съездов КПСС, сессий Верховного Совета; во время многочисленных экспедиций, поездок, лекций, конгрессов.

Экспонируются орденские книжки кавалера многочисленных правительственных наград, Героя Социалистического Труда, кавалера шести орденов Ленина, лауреата трех государственных премий. Принципиальную позицию ученого раскрывают материалы об отказе от очередного ордена в знак протеста против нефтяной политики государства в 1990-е гг.

Выражением глубокого уважения к деятельности ученого является свидетельство, выданное администрацией Новосибирской области (2000) о признании благодарными земляками в канун нового XXI столетия А. А. Трофимука Гражданином XX века Новосибирской области. В нем указано, что «Гражданин XX века - это человек, которым по праву гордятся новосибирцы, чья деятельность прославила край далеко за его пределами. Его жизненный путь и спустя много лет будет примером беззаветного служения Родине». Свидетельство Государственного геолого-минералогического музея им. В. И. Вернадского РАН (Москва) удостоверяет, что имя академика А. А. Трофимука в знак глубокой признательности за благородные деяния по развитию отечественной науки внесено в Летопись музея (1998).

Важное значение имеет рукописный фонд А. А. Трофимука. Сохранились 53 записные книжки и 8 ежедневников, которые содержат подробные записи о буровых испытаниях в Западной и Восточной Сибири, Башкирии, научной работе во время поездок в США (1963), Индию (1964), поездках с президентом АН СССР академиком А. П. Александровым в Томск, Тюмень, Сургут, Нижневартовск (1977), рукопись вступительного слова на V Губкинских чтениях» (1986).

Прекрасным украшением кабинета являются подарки из поделочных и полудрагоценных камней - яшмы, оникса, родонита, алмазонита, чароита, аметиста, нефрита с дизайном в виде нефтяных вышек, геологических молотков, географических карт Сибири и Башкирии, а также выполненные сибирскими художниками портреты А. А. Трофимука, многочисленные пейзажи Сибири, Алтая, озера Байкал, виды Новосибирского академгородка. 
Из личных вещей экспонируются барометры, тренажер для физических упражнений, очки, лупа, авторучки, электронный калькулятор, рыболовные и охотничьи снасти, ножи, таксидермические скульптуры крупных пернатых Сибири, китель и предметы гардероба, относящиеся к периоду службы в Главнефтеразведке Министерства нефтяной промышленности СССР, капсула с белорусской землей с места рождения А. А. Трофимука (деревня Федьковичи, Жабинковского района, Брестской области).

Личная библиотека содержит около тысячи томов по всем разделам нефтегазовой геологии. Материалы музея использовались при подготовке книги об А. А. Трофимуке «Главный геолог».

В 1985 г. в Институте катализа СО РАН создан мемориальный кабинет академика Г. К. Борескова (1907-1984) - физикохимика, первого директора Института катализа СО РАН (1958-1984) - крупнейшего в мире научно-исследовательского центра в области катализа, носящего с 1991 г. имя Г. К. Борескова.

Музей создавался на общественных началах под руководством директора Института катализа СО АН СССР академика К. И. Замараева (1984-1995). Открытие состоялось 21 июня 1987 г., в день начала работы международной научной конференции «Современные проблемы катализа», посвященной 80-летию со дня рождения Г. К. Борескова. В 1997 г. по приказу директора, академика В. Н. Пармона (1995-2017) музей приобрел статус подразделения института.

Основу фондовых коллекций составили материалы, переданные вдовой ученого М. В. Чайкиной-Боресковой. О рождении Г. К. Борескова в Омске в 1907 г. свидетельствует фотокопия записи священника Крестовоздвиженской церкви в метрической книге. Уникальные семейные фотографии запечатлели родителей, принадлежавших к старинным дворянским семьям: отец К. М. Боресков - один из первых военных авиаторов России, дед М. М. Боресков - генерал-лейтенант, крупный военный ученый-инженер. Демонстрируется медальон с портретом матери Иды Петровны. Воспоминания сестры друга Г. К. Борескова - Н. А. Мандражи, написанные в 1987 г., повествуют о детстве и юности ученого.

Годы учебы и работы в Одессе отражены в свидетельстве об окончании Одесского химического института; в учебниках студента Борескова; лабораторных журналах за 1928-1932 гг. с записями об опытах с катализаторами под руководством профессора И. Е. Ададурова; справке Одесского индустриального института о том, что доцент Боресков в 1930-1937 гг. читал курс «Процессы и аппараты химической промышленности»; в изданных в 1936 г. в Одессе курсах лекций Г. К. Борескова; в конспектах лекций ученого по курсу «Технология серной кислоты», записанных в 1936 г. Е. Кричевской.

Годы жизни и деятельности Г. К. Борескова в Сибирском отделении АН СССР, куда он переехал в связи с назначением на должность директора Института катализа, иллюстрируются исторической фотографией, на которой запечатлен момент разрезания ученым ленточки на крыльце здания Института катализа в мае 1963 г. Представлены дипломы об избрании Г. К. Борескова членом-корреспондентом и действительным членом АН СССР, удостоверение действительного члена АН СССР, подписанное президентом АН СССР М. В. Келдышем, дипломы лауреата Государственной премии Украинской ССР (1970), почетного доктора Honoris Causa Вроцлавского политехнического института в Польше (1976) и Университета Пуатье во Франции (1980), медаль «Пауль Сабатье. Нобелевский лауреат 1912 г.», Грамота Президиума Верховного Совета СССР о награждении Института катализа орденом Трудового Красного Знамени (1969), более 70 авторских свидетельств и патентов, в т. ч. первый патент на изобретение, полученный в 1930 г. в соавторстве с профес- 
сором И. Е. Ададуровым, диплом о награждении Института катализа СО АН СССР международной премией «Золотой Меркурий» (1980), свидетельствующей о высоких результатах научно-исследовательской деятельности как самого ученого, так и возглавляемого им института.

Личная библиотека, снабженная электронным каталогом, насчитывает более тысячи книг, в т. ч. Уникальных, изданных в конце XIX - начале XX в., имеющих дарственные надписи.

Демонстрируются предметы интерьера рабочего кабинета: письменный стол, кейс, с которым Г. К. Боресков выезжал в свою последнюю командировку в ФРГ, Западный Берлин на VIII Международный конгресс по катализу (1984), печатная машинка Erika-10, мантия и головной убор почетного доктора Вроцлавского политехнического института (1976), мантия, головной убор и меховой наплечник почетного доктора Университета Пуатье, Франция (1981), рыболовный ящик со снастями для зимней рыбалки. В последние дни своей жизни ученый пользовался сборником трудов VIII Международного конгресса по катализу (1984), англо-русским словарем, очками с футляром, ручкой и тетрадью с записями, которые обрываются фразой: «Время существования на поверхности молекул этилидина много больше времени реакции...».

В 1987 г. в Институте цитологии и генетики СО РАН открылся мемориальный кабинет Д. К. Беляева (1917-1985) - директора Института цитологии и генетики СО РАН (1959-1985), зам. председателя Президиума СО АН СССР (1976-1985), одного из крупнейших советских генетиков, наиболее известного своим экспериментом по выведению одомашненных лис.

Мемориальная комната Д. К. Беляева создана по инициативе директора Института академика В. К. Шумного (1986-2007). Обширный фотоматериал, сгруппированный в фотоальбомы, документирует жизненный путь ученого: детство в с. Протасово Костромской губернии, учебу на зоотехническом факультете Ивановского сельскохозяйственного института, проявленный героизм на фронтах Великой Отечественной войны, начало трудовой деятельности в Центральной исследовательской лаборатории Министерства внешней торговли СССР в 1946-1958 гг., работу в Сибирском отделении.

Процесс возрождения генетики в Сибири отражает портретная галерея работников института в 1957-1961 гг. - Н. П. Дубинина, Д. К. Беляева, П. К. Шкварникова, Ю. Я. Керкиса, Г. Ф. Привалова, А. Н. Луткова, Ю. П. Мирюты, В. В. Хвостова, В. Б. Енкена, 3. С. Никоро, Ю. О. Раушенбаха, Н. Б. Христолюбова, В. А. Ратнера, Р. Л. Берг.

Экспонируются: диплом Президиума АН СССР о присуждении академику Д. К. Беляеву и доктору биологических наук Л. Н. Трут премии имени Н. И. Вавилова за серию работ на тему «Экспериментальное исследование доместикации животных» (1982); Большая золотая медаль Д. К. Беляева «За заслуги перед наукой и человечеством» - высшая награда АН бывшей Чехословакии; фронтовые личные вещи: блокнот, кисет, письма, фотографии; бюст Н. И. Вавилова - подарок конференции, посвященной 90-летию со дня рождения Н. И. Вавилова в Саратове (1977 г., автор К. С. Суминов); макет танка - подарок Военного совета Сибирского военного округа в день 60-летия ученого.

Музей участвовал в подготовке книги воспоминаний о Д. К. Беляеве из серии «Наука Сибири в лицах», документального фильма «Военная страница биографии академика Д. К. Беляева» (реж. В. Ф. Древич), многочисленных научно-биографических статей о известных ученых-генетиках. В 2018 г. на базе мемориального музея Д. К. Беляева открыт Музей истории генетики в Сибири как структурное подразделение Института цитологии и генетики СО РАН. 
В Институте катализа СО РАН действует мемориальная комната-кабинет академика К. И. Замараева (1939-1996) - выдающегося физикохимика, специалиста в области химической кинетики в конденсированных средах, катализа, химической радиоспектроскопии. К. И. Замараев сменил Г. К. Борескова на посту директора Института катализа СО АН - СО РАН (1984-1995), сохранил и приумножил научный потенциал института.

Мемориальная комната организована в 1996 г. по инициативе директора института академика В. Н. Пармона. До 2000 г. комната находилась в ведении Международного благотворительного фонда им. К. И. Замараева во главе с его исполнительным директором, вдовой ученого Л. А. Замараевой, учредившей также стипендии, исследовательские гранты и премии для молодых ученых. С 2001 г. комната является подразделением института.

Фотографии, документы, награды, личные вещи документируют этапы жизни и деятельности академика. Экспонируются материалы об его деде - К. И. Замараеве, преподавателе начертательной геометрии в Санкт-Петербургском университете и Томском технологическом институте; отце - И. К. Замараеве, крупном советском инженере-химике, лауреате Государственной премии за решение чрезвычайно сложной технологической задачи - пуска первого отечественного цеха по производству синильной кислоты в годы Великой Отечественной войны.

Интерес вызывают: золотая медаль К. И. Замараева - выпускника первой в Москве специализированной английской школы; лекции и рабочие тетради Замараевааспиранта, которые показывают, что огромную роль в становлении его как ученого сыграли научный руководитель академик В. В. Воеводский и академик Н. Н. Семенов.

Обширный материал документирует годы учебы сталинского стипендиата К. И. Замараева в Московском химико-технологическом институте им. Д. И. Менделеева и Московском физико-техническом институте, научно-исследовательской и преподавательской работы в Институте химической физики им. Н. Н. Семенова АН СССР (1966-1977), Московском физико-техническом институте, Корнельском, Стенфордском и Чикагском университетах (США, 1974-1975), сибирский период жизни: переезд члена-корреспондента АН СССР К. И. Замараева с женой и сыном в Новосибирский академгородок во главе большой команды выпускников Московского физико-технического института - специалистов по химической физике (1977).

О крупном вкладе К. И. Замараева в развитие теории и практики каталитической науки свидетельствуют документы о правительственных наградах - орденах «Знак Почета» (1982) и Трудового Красного Знамени (1986); удостоверение директора Института катализа СО АН, подписанное академиком В. А. Коптюгом (1987); диплом об избрании действительным членом АН СССР (1987); Почетная грамота Верховного Совета РСФСР (1990); медаль и диплом Почетного члена Корейской академии наук и технологий (1995); диплом об избрании членом Индийской национальной академии наук (1994); диплом и значок члена Академии Европы; медаль А. П. Карпинского и диплом о награждении премией А. П. Карпинского за работы в области экологического катализа (1995). Фото о вручении серебряной медали и диплома Королевского химического общества Великобритании «Лектор столетия» за цикл лекций, прочитанных в 1994-1995 гг. в университетах и научных центрах Великобритании, свидетельствует о выдающемся лекторском мастерстве ученого.

Личная библиотека по проблемам физической химии снабжена электронным каталогом, включенным в каталог научной библиотеки института. Сотрудники мемориальной комнаты вводят в научный оборот материалы о крупных представителях российских каталитиков - А. М. Бутлерове, В. Н. Ипатьеве, С. В. Лебедеве, Н. Д. Зелинском, А. А. Баландине, Г. К. Борескове, К. И. Замараеве. На выставке «Катали- 
заторы, внедренные институтом катализа за период его деятельности», экспонируются коллекции катализаторов, лекарственных препаратов и товаров народного потребления, изготовленных на основе разработок института [Музеи СО РАН 2009].

В ряде академических институтов СО РАН имеются музейные структуры, представляющие историю институтов, научные школы и выдающихся ученых. В Институте систем энергетики СО РАН в 1980 г. создан музей истории института с разделами, посвященными деятельности директоров - академиков РАН Л. А. Мелентьева, Ю. Н. Руденко и члена-корреспондента РАН А. П. Меренкова. В Институте земной коры СО РАН с 1995 г. экспонируются фрагменты мемориальных кабинетов директоров М. М. Одинцова, Н. А. Логачева, Н. А. Флоренсова. В Институте горного дела СО РАН с 1999 г. экспонируются мемориальные комплексы директоров Н. А. Чинакала, Е. И. Шемякина, М. В. Курленя, Т. Ф. Горбачева, Г. И. Грицко. В Институте органической химии СО РАН им. Н. Н. Ворожцова с 1998 г. хранятся мемориальные комплексы директоров - академика Н. Н. Ворожцова и члена-корреспондента АН СССР В. П. Мамаева. В Институте экономики и организации промышленного производства СО РАН создаются мемориальные кабинеты директоров - члена-корреспондента АН СССР Г. А. Пруденского, академиков РАН А. Г. Аганбегяна, А. Г. Гранберга, В. В. Кулешова.

Ценнейшее качество наследия, как отмечал Т. С. Шола, - способность связывать нас с реальностью. Миссия искусства публичной памяти, заключающаяся в служении обществу, появилась и стала востребована с развитием современного понятия гражданственности [Шола 2017: 59]. В этом смысле мемориальные комнаты образуют особую форму публичной памяти о выдающихся личностях. Многолетний опыт деятельности выявил и закрепил их вполне определенную институциональную идентичность, для которой характерные следующие черты. Небольшие по размеру экспозиционно-выставочные пространства мемориальных комнат демонстрируют органическое единство вещного микромира, окружавшего ученых, с глобальной значимостью результатов их интеллектуального труда. Они дают наглядные представления о реальном процессе развития науки, документируют уникальность вклада ее выдающихся представителей, транслируют индивидуально-биографические образы, служащие примером достойного служения науке, отечеству, творческой самореализации личности, проявления гражданской позиции в драматических условиях эпохального исторического значения. Фондовые коллекции мемориальных комнат служат основой для научно-исследовательской, издательской, научно-образовательной и научно-просветительной деятельности. Таким образом, предложенная и интерпретированная метареальность мемориальных комнат известных ученых является эффективным инструментарием для пользы, развития и совершенствования общества.

\section{Аитература}

Авруцкая Т. Б. Мемориальный кабинет-музей Н. И. Вавилова / Т. Б. Авруцкая; отв. ред. Т. И. Алексеева // Музеи Российской академии наук. Альманах-2003. - М.: Научный мир, 2005. $-284 \mathrm{c}$.

Виноградова Л. П. Мемориальный кабинет-музей академика А. П. Виноградова / Л. П. Виноградова // Музеи Российской академии наук. Альманах-1998. - М.: Научный мир, 1998. $-344 \mathrm{c}$.

Гайдукова Н. М. Дом-музей академиков А. Е. и Б. А. Арбузовых в Казани / Н. М. Гайдукова, Н. С. Кореева // Музеи Российской академии наук. Альманах-2001. - М.: Научный мир, 2002. - 312 с.

Езерова Г. Н. Жизнь в делах продолжается... / Г. Н. Езерова // Музеи Российской академии наук. Альманах-1998. - М.: Научный мир, 1998. - 344 с. 
Захарова Т. Г. Мемориальный музей Н. А. Морозова / Т. Г. Захарова // Музеи Российской академии наук. Альманах-1998. - М.: Научный мир, 1998. - 344 с.

Ивановская И. Н. От домашнего кабинета до мемориального кабинета-музея (к 60-летнему юбилею кабинета-музея В. И. Вернадского) / И. Н. Ивановская // Музеи Российской Академии наук. Альманах. Вып. 10. - М.: Таус, 2013. - 280 с.

Калашникова И. С. Академик Николай Альфредович Платэ / И. С. Калашникова, Л. А. Нехаева // Музеи Российской академии наук. Альманах. Вып. 9. - М.: Таус, 2012. - 272 с.

Камшилова О. Ф. Музей И. Д. Папанина / О. Ф. Камшилова // Музеи Российской академии наук. Альманах-1998. - М.: Научный мир, 1998. - 344 с.

Карпеев Э. П. Музей М. В. Ломоносова / Э. П. Карпеев // Музеи Российской академии наук. Альманах-1998. - М.: Научный мир, 1998. - 344 с.

Куприянова Н. К. Мемориальный музей-квартира академика И. П. Павлова / Н. К. Куприянова // Музеи Российской академии наук. Альманах-1998; отв. ред. Т. И. Алексеева. М.: Научный мир, 1998. - 344 с.

Леонова $E$. B. Мемориальный кабинет-музей - фундамент в подготовке молодых ученых / Е. В. Леонова, В. В. Гуменюк // Музеи Российской академии наук. Альманах. Вып. 9. M.: Tayc, 2012.- $272 \mathrm{c}$.

Мемориальная комната академика В. А. Коптюга [Электронный ресурс]. - Режим доступа: http://turizmnso.ru/sights/?SECTION_ID=12\&ELEMENT_ID=1063 (дата обращения: 15.03.2019).

Музеи СО РАН. Музеи научных центров и институтов Сибирского отделения российской академии наук. Очерки формирования и развития. - Новосибирск, 2009. - 262 с.

Нехаева Л. А. Мемориальный кабинет академика С. С. Наметкина / Л. А. Нехаева, О. П. Паренаго // Музеи Российской академии наук. Альманах-2000. - М.: Научный мир, 2002. $-240 \mathrm{c}$.

Покровский Н. Н. Достопримечательное место «Новосибирский Академгородок»: научное и историко-культурное наследие / Н. Н. Покровский, Г. М. Запорожченко, О. Н. Шелегина. - Новосибирск: ИПЦ НГУ, 2018. - 128 с.

Пономарева И. П. Мемориальный кабинет академика В. В. Парина / И. П. Пономарева // Музеи Российской академии наук. Альманах-2001. - М.: Научный мир, 2002. - 312 с.

Рубинин Е. П. Мемориальный музей П. Л. Капицы. Как он создавался / Е. П. Рубинин // Музеи Российской академии наук. Альманах. Вып. 9. - М.: Таус, 2012. - 272 с.

Хрущева Е. И. К созданию мемориального кабинета академика А. Н. Фрумкина / Е. И. Хрущева // Музеи Российской академии наук. Альманах-2003. - М.: Научный мир, 2005. $284 \mathrm{c}$.

Шола Томислав С. Мнемософия. Эссе о науке публичной памяти / Томислав С. Шола / ИКОМ России; ГМЗ «Ростовский Кремль». - Ростов Великий, 2017. - 320 с.

\section{References}

Avruckaya T. B. Memorial'nyj kabinet-muzej N. I. Vavilova / T. B. Avruckaya; otv. red. T. I. Alekseeva // Muzei Rossijskoj akademii nauk. Al'manah-2003. - M.: Nauchnyj mir, 2005. - $284 \mathrm{~s}$.

Vinogradova L. P. Memorial'nyj kabinet-muzej akademika A. P. Vinogradova / L. P. Vinogradova // Muzei Rossijskoj akademii nauk. Al'manah-1998. - M.: Nauchnyj mir, 1998. - 344 s.

Gajdukova N. M. Dom-muzej akademikov A. E. i B. A. Arbuzovyh v Kazani / N. M. Gajdukova, N. S. Koreeva // Muzei Rossijskoj akademii nauk. Al'manah-2001. - M.: Nauchnyj mir, 2002. $-312 \mathrm{~s}$.

Ezerova G. N. Zhizn'v delah prodolzhaetsya... / G. N. Ezerova // Muzei Rossijskoj akademii nauk. Al'manah-1998. - M.: Nauchnyj mir, 1998. - 344 s.

Zaharova T. G. Memorial'nyj muzej N. A. Morozova / T. G. Zaharova // Muzei Rossijskoj akademii nauk. Al'manah-1998. - M.: Nauchnyj mir, 1998. - 344 s.

Ivanovskaya I. N. Ot domashnego kabineta do memorial'nogo kabineta-muzeya (k 60-letnemu yubileyu kabineta-muzeya V. I. Vernadskogo) / I. N. Ivanovskaya // Muzei Rossijskoj Akademii nauk. Al'manah. Vyp. 10. - M.: Taus, 2013. -280 s. 
Kalashnikova I. S. Akademik Nikolaj Al'fredovich Plate / I. S. Kalashnikova, L. A. Nehaeva // Muzei Rossijskoj akademii nauk. Al'manah. Vyp. 9. - M.: Taus, 2012. - 272 s.

Kamshilova O. F. Muzej I. D. Papanina / O. F. Kamshilova // Muzei Rossijskoj akademii nauk. Al'manah-1998. - M.: Nauchnyj mir, 1998. - $344 \mathrm{~s}$.

Karpeev E. P. Muzej M. V. Lomonosova / E. P. Karpeev // Muzei Rossijskoj akademii nauk. Al'manah-1998. - M.: Nauchnyj mir, 1998. - 344 s.

Kupriyanova N. K. Memorial'nyj muzej-kvartira akademika I. P. Pavlova / N. K. Kupriyanova // Muzei Rossijskoj akademii nauk. Al'manah-1998; otv. red. T. I. Alekseeva. - M.: Nauchnyj mir, 1998. - $344 \mathrm{~s}$.

Leonova E. V. Memorial'nyj kabinet-muzej - fundament v podgotovke molodyh uchenyh / E. V. Leonova, V. V. Gumenyuk // Muzei Rossijskoj akademii nauk. Al'manah. Vyp. 9. - M.: Taus, 2012.- $272 \mathrm{~s}$.

Memorial'naya komnata akademika V. A. Koptyuga [Elektronnyj resurs]. - Rezhim dostupa: http://turizmnso.ru/sights/?SECTION_ID=12\&ELEMENT_ID=1063 (data obrashcheniya: 15.03.2019).

Muzei SO RAN. Muzei nauchnyh centrov i institutov Sibirskogo otdeleniya rossijskoj akademii nauk. Ocherki formirovaniya i razvitiya. - Novosibirsk, 2009. - 262 s.

Nehaeva L. A. Memorial'nyj kabinet akademika S. S. Nametkina / L. A. Nehaeva, O. P. Parenago // Muzei Rossijskoj akademii nauk. Al'manah-2000. - M.: Nauchnyj mir, 2002. - $240 \mathrm{~s}$.

Pokrovskij N. N. Dostoprimechatel'noe mesto «Novosibirskij Akademgorodok»: nauchnoe i istoriko-kul'turnoe nasledie / N. N. Pokrovskij, G. M. Zaporozhchenko, O. N. Shelegina. - Novosibirsk: IPC NGU, 2018. - $128 \mathrm{~s}$.

Ponomareva I. P. Memorial'nyj kabinet akademika V. V. Parina / I. P. Ponomareva // Muzei Rossijskoj akademii nauk. Al'manah-2001. - M.: Nauchnyj mir, 2002. - $312 \mathrm{~s}$.

Rubinin E. P. Memorial'nyj muzej P. L. Kapicy. Kak on sozdavalsya / E. P. Rubinin // Muzei Rossijskoj akademii nauk. Al'manah. Vyp. 9. - M.: Taus, 2012. - 272 s.

Hrushcheva E. I. K sozdaniyu memorial'nogo kabineta akademika A. N. Frumkina / E. I. Hrushcheva // Muzei Rossijskoj akademii nauk. Al'manah-2003. - M.: Nauchnyj mir, 2005. - 284 s. Shola Tomislav S. Mnemosofiya. Esse o nauke publichnoj pamyati / Tomislav S. Shola // IKOM Rossii; GMZ «Rostovskij Kreml’». - Rostov Velikij, 2017. - 320 s. 